\title{
Ali Miller on Key Strategies
}

\author{
An Interview with Alice Miller conducted by Marilou McPhedran
}

Alice (Ali)Miller, is currently a Rockefeller Fellowat the Program for the Study of Sexuality, Gender, Health and Human Rights, at Columbia University's School of Public Health. She is on sabbatical from her position as the Director of the Women's Rights Advocacy Program (WRAP) of the International Human Rights Law Group. Founded in 1978, this Washington-based advocacy organization seeks to mobilize the skills of legal professionals, to work in partnerships transcending national borders, in order to actualize the progressive development and implementation of a complete protection of human rights-civil, cultural, economic, political and social-for women and men. Goals include ensuring locally realized government accountability, including that of the United States, to international human rights standards, as well as a full understanding of the impact of gender and race on people's ability to enjoy their rights.

In December of 1998, Marilou McPhedran interviewed Ms. Miller, exploring with her several key action strategies for both academics and advocates. On January 29, 1998, Ms. Miller had chaired a NGO Roundtable on "The Meaning of Trafficking in Persons," discussing trends and solutions to forced human labour, a summary of which will be published in Rutgers University Women's Rights Law Reporter, Volume 20, Number 1, Fall/Winter 1998. Appendix 1 contains excerpts from the round table summary, printed here courtesy of the Rapporteur, Alison Stewart, a staff attorney at the International Human Rights Law Group, and the Women's Rights Law Reporter. Appendix 2 contains the recommendations from the June 1998 Transnational Training Seminar on Trafficking in Women in Budapest, Hungary. Provided by GAATW-Canada, Appendix 3 contains updated revised Standards of Minimum

Marilou McPhedran C.M., LL.B., LL.D. (Hon.) is the Project Director, International Women's Rights, and the Director of the CEDAW Impact Study and Network, at the Centre for Feminist Research, York University, Toronto.
Rules for humanitarian treatment of trafficked persons.

[Excerpts from the Roundtable summary included in the text of this interview are indicated by square brackets.]

MarilouMcPhedran for Refuge: Ali, the term" trafficking" seems to mean different things and include different activities, when appearing in policies and laws. Which definition of trafficking do you consider most helpful at this time? Ali Miller: We are looking to define the word "trafficking" in such a way that it captures what is abusive in actual, existing practices. "Trafficking" is a word that vibrates with no edges-it has immediate popular power, but that popular understanding tends to reduce diverse and complicated economic, labour, gender, and power issues, to talking nervously about sex. Constructive work to end trafficking in humans is thus hampered by how societies respond to sex. Many of us working on the problem at a global level have begun to reach certain understandings. Although trafficking is a highly gendered construction, it is important to remember that, internationally, there is a problem in trafficking in persons, not just in women. Simply, "trafficking" denotesa set of practices which coercively moves people into work in which they did not intend to be, which treats them like commodities. Because of the local and international nature of gendered hierarchies of power, the reality of what the market offers women is often different than what it offers men and, in many cases, but not all, results in sexual activity for money.

Internationally, a formal defining of trafficking is still in progress, with many different interests, including NGOs, women's groups, and governments, assessing which definition captures the problem they want to eliminate. Not all of these entities are interested in protecting the human rights of those being trafficked, however.

[Roundtable excerpt on the definition of trafficking:

It is important to remember that the historical understanding of trafficking in international law has been focused primarily of the movement of persons, mostly women, across borders for the purpose of prostitution. For example, see the 1949 Convention on the Suppression of the Traffic in Persons and of the Exploitation of the Prostitution of Others ("the Trafficking Convention").

The Roundtable participants identified problems with and ultimately rejected each key element of the "classic" definitions-namely the borders requirement, the exclusive focus on prostitution, and the "with or without" consent aspects.

1. Rejecting the crossing of borders requirement.

The Roundtable participants concluded that there are some factors associated with border crossing that have made it a central element of traditional definitions of trafficking. Those factors include movement to a foreign or unfamiliar milieu; victims having illegal or non-national status; language, cultural or other barriers; and separation from family and community.

The group agreed that many of these conditions were satisfied without crossing borders. However, a "constructive" or "substitute" border crossing of some geographical or political boundary, would seem to suffice. For instance, moving from a rural to metropolitan area or to a region where a different language is spoken, such as moving Hill Tribe women into the city.

The critical issues underlying the "traffic" element are that the victims are "moved" to an unfamiliar milieu, are disconnected from family, community and friends, are given only limited access to the usual support systems and services, are isolated physically, emo- 
tionally or by language or other cultural barriers, are denied legal identity or access to justice, and are, therefore, at greater risk of abuse, violence, exploitation, domination and discrimination.

For practical, legal and remedial purposes, international or intra-national border crossing is highly relevant-such as deportation and denial of services on the grounds of alienage.

2. Rejecting the requirement of trafficking for the purpose of prostitution: It was uniformly agreed that people can be and are traded for a wide variety of purposes including, but not limited to prostitution or other sex-work (whether legal or illegal) domestic, manual or industrial labour (whether in the formal or informal sector) and marriage, adoptive or other intimate relationships (whether real or sham).

Prostitution per se as the exclusive purpose of trafficking is an untenable definition as not all trafficking victims are prostitutes nor have all prostitutes been trafficked.

Those who are tricked into working under abusive or exploitative labour conditions would be considered trafficking victims as they agreed to work in the sex industrybut not to the grave psychological, emotional or physical abuse or violence.

3. Rejecting the notion that one could be trafficked, even with one's consent:

It was agreed that respect for the agency of persons, especially women, should be a fundamental aspect of any new definition. Priority attention must be paid to what conditions are necessary for persons, especially women, to make decisions-rights of information, freedom from coercion, discrimination etc.

Distinations should beclearly drawn between trafficking and the separate criminal offences of illegal migration and alien smuggling, i.e., willingly and knowingly attempting to enter the country illegally. Distinguishing alien smuggling from trafficking may be problematic as those third parties are often linked to a larger "pipeline" of suppliers, guides, facilitators, transporters and receivers-all of whom usually have actual or constructive knowledge of the conditions awaiting the smuggled persons.

It was agreed that movementmust be truly consensual and voluntary in order not to be considered trafficking. Thus, the consent given must be a full and informed consent as to both the movement and the end-conditions.]

Refuge: Ali, you started to advocate for counter measures to trafficking-especially for using a human rights approach-long before this issue was "discovered". What are your observations on recent shifts in attitude and action, on an international scale, with regards to trafficking?

AliMiller: Well, although "trafficking" as an issue has appeared suddenly to hit the top of the international agenda (speeches by heads of state, world conferences on commercial sexual exploitation of children, IGO interest in new standards), those of us working in this field-and I must say that activists in Southeast and Southern Asia, and in Western Europe, particularly in the Netherlands and Belgium, have led the way toward responding progressively-are concerned with what the government response has actually been. Governments have tended to take those steps which are easiest to carry out without having to change fundamental structures of inequality or economic oppression-punitive law enforcement, rather than any protection of the human rights of those men, women, and children who are forced to labour without fair pay. Underlying these responses is the subtext that governments, in line with historical attitudes, tend to recognize only the mostinnocent of the innocent as worthy of protection-i.e., the woman kidnapped into sex work. Yet the reality for girls and women in many countries is that there is little choice as far as marriage or sex work is concerned-in few cases do women have the economic security, personal integrity, or support to make a choicenot to exchangesex for some form of survival.

Examples of bad government response are legion. For example, when international concern first peaked, in 1993 and 1994, NGOs in Thailand were concerned about a policy of denying visas to young Thai women existing as a form of protection against the moving of Thai women into Europe for purposes of forced prostitution. The Philippines, which has based much of its economy on the export of labour, has episodically halted and reinstated practices concerning the granting of visas to women seeking work abroad-targeting the women, rather than attempting to improve the treatment of their own citizens in other countries through bilateral negotiations. In Canada and the United States, governments have shown their main response to be the prosecution of women brought into the country for sex work, meanwhile charging the brothel owners with "trafficking," or deporting women with no regard for the conditions to which they are returned. Few resources are put into protecting these women or effectively countering the well-organized forces bringing women into the country to service the lucrative sex market. In bilateral initiatives between the United States, Russia and the Ukraine, the rhetoric has emphasized rights, but the bulk of the money has been spent on government systems, ostensibly for prosecutions, not for protection of rights. Few countries have invested in support systems for trafficked people. And the reality of most government action is that it rarely addresses the corrupt practices enabling the traffickers to thrive. Governments do not address the economic conditions and discrimination putting women at risk, focusing instead on the conspiracies. So much so that they fail to prosecute the abuses carried out as constituentelements of trafficking, such as kidnapping and forced labour, rape and debtbondage.

Refuge: Can you give an example of a model for more constructive responses? Ali Miller: In Belgium, there is an NGO called "Payoke," which has organized two related programs. Payoke says that both programs are necessary, as they provide support and advocate for the rights of both those women who say they wish to remain in prostitution and those that wish to leave. Over the years, the organization has been increasingly 
contacted by women who have been trafficked and need assistance. Payoke has worked with the government of Belgium to provide services (legal, economic assistance, medical care and counselling) to trafficked persons, and extended stays (through withholding of deportation) to persons who agree to participate in the prosecution of traffickers.

Refuge: Ali, this Belgian example prompts me to ask for your assessment of the current challenges faced by the advocacy movement.

Ali Miller: The questions surrounding the legitimacy of sex work are a source of tension within and between many of the advocacy organizations now. After years of defining the problem as "sex trafficking in women and children," many advocates in different countries are shifting their analysis, to situate trafficking in the context of broader migration trends, social, and economic development. At the same time, it's essential to expand the gender analysis of these trends (See Appendix 1).

Recent meetings in Budapest, Victoria and $W$ ashington have reinforced the need re-conceptualize trafficking in the larger economic context (See Appendix 2). In Budapest, Mary Robinson, the $U N$ High Commissioner for Human Rights, called for the decriminalization of prostitution. In addition, we need to step back from the headline-grabbing sex trade emphasis and deal with the fact that advocacy and support work in this area can be dangerous work. Local organizations face limitations and risks that are not always appreciated by the international advocates, or acknowledged by diplomats. Weneed todevelop long-term strategies about how to act safely, because trafficking is so often part of ruthless business conducted by violent, efficient, criminal organizations who act and retaliate with impunity. Local advocates located in both the sending and the receiving countries may be those best situated to gather information; the voices of the women who have been trafficked need to be listened to, but they are also vulnerable to intimidation and retaliation, or silenced by their caretakers, who claim to "know what's best." Local groups need the protection of revised local laws, including those affecting communication and information flow, so they can network to provide services across country borders. Trafficking is inter-regional. So, effective change requires complementary international laws and co-operation standards.

Refuge: Ali, what are your recommendations for three key strategies for constructive action at this time?

Ali Miller: There are many initiatives underway that address the central goal of rights protection. Current international law conflates all of trafficking. It is insufficient, and not responsive to the currentrealities of trafficked people. The agency, or autonomy, of trafficking victims is not acknowledged, and this is a primary fault of current legal instruments. There can be no effectiverights protection without recognition of personal autonomy and the rights essential for giving effect to the desires and needs of those trafficked. It's now widely understood that prosecuting sex trade workers is a bad and ineffective strategy.

Constructive action flows from sound principles. Reconceptualization and gender analysis of trafficking are now informing advocacy, which is focused on utilizing international conventions and treaties more effectively (see Appendices). Although we know that the international legal instruments are in many respects outdated, it's clear that our energies are best directed to upgrading what we have available now, instead of trying to bring in whole new legal instruments or treaty bodies. On the other hand, there are indications that various governmental and IGO bodies want new instruments to strengthen their hand in fighting international crime-we are picking our way through the strategy choices, weighing the likelihood that new instruments will be rights protective, assessing the best use for our current limited resources, and the immediate need for action.

Three key strategies for 1999 are to:

1. Continue the work underway, to reach agreement among national
NGO on rights protective strategies, through research, dialogueand consultation. Strategies should reflect the broad range of humanneeds enveloped within the term "trafficking." Develop and implement fundamental principles of autonomy and conditions needed to allow individuals to make choices. Guide development of a human rights framework and resulting strategies to end trafficking utilizing a gender analysis of power and economicconditions. The Global Alliance Against Trafficking in Women (GAATW) is attempting to co-ordinate advocacy concerned with minimum standards for the treatment of trafficked persons(See Appendix 3). NGOsare bringing these human rights concerns to all the relevant human rights treaty bodies, as well as participating in the development of instruments, such as the proposed Optional Protocol for the Convention on the Elimination of All Forms of Discrimination Against Women (CEDAW), to ensure that a broad range of trafficking cases can be brought before such treaty bodies.

2. Further the understanding of the constituent elements of trafficking. identifying which ones already exist as crimes, in order to develop countermeasures which vindicate the rights of abused persons and do not recriminalize the victims of trafficking. Working with women whohave been trafficked, as well as establishing a network of services across and within national borders, will be essential to this understanding.

3. Monitor and utilise the responsibilities and resources available through those IGO structures capable of speaking to multiple governments, including the Office of the UN High Commissioner for Human Rights, the Council of Europe, the Vienna Commission on Crime Prevention and Control, and other regional bodies, including the EU, ASEAN and SAARC. This requires networks of advocates briefed on existinghuman rights obligations to guide new initiatives by governments, such as 
ending the limiting of women's freedom of movement, by applying international legal standards to local and national situations, in the manner of the Standards for the Humanitarian Treatment of Trafficked Persons developed by GAATW.

\section{Appendix 1}

Additional excerpts from the Roundtable discussion chaired by Alice Miller reveal the complexities faced by those working to address, define, target, and eliminate the trafficking of persons around the world:

\section{The Issues}

The historical linkage of "women and children" is problematic for women's rights in three ways. It has often figuratively or factually encompassed treatment of women as if women had the same rights as children. Indeed, in all countries, at one time women werelegal minors and in many countries women still lack full adult legal capacity. Secondly, the linkage serves to emphasize the role of women solely as caretakers of children. While it is true that women predominantly function as family caretakers in all parts of the world, women also have concerns and rights outside of that role. Finally, if the pairing of women and children is meant to signify the linkage of gender discrimination for females throughout their life cycle (infancy, childhood, adolescence, adulthood, old age), the phrase should be "women and girls" so as not to eclipse the separate conditions and concerns of male children.

The adult/child distinction is further complicated by the fact that trafficking can and often does affect girl-children and boy-children differently. For example, girl-children are often placed in trafficking situations for different reasons, trafficked into different kinds of work or relationships, face different types of violations or abuse, and areafforded different remedies and social opportunities than boy-children. Girl-children are most often trafficked for their virginity (real or imagined) into marriage or the sex industry, while boychildren are most often trafficked into sweatshop or other similar labour. Thus, it is not entirely useful to collapse girl-children and boy-children into one category of trafficking victims. Due to the gendered nature of trafficking, the situation of girl-children is often more similar to that of trafficked women than trafficked boy-children. Women and girls are primarily trafficked for sex and reproduction, as well as labour deemed to be "women's work," while boy-children are trafficked primarily as a source of cheap factory or similar labour. Certainly girls are trafficked into sweatshops and boys are trafficked into the sex industry; however, girls represent the overwhelming majority of all children trafficked into the sex industry.

In regard to the question of initiatives focusing on trafficking in women or on trafficking in persons, the participants considered the model of the Violence Against Women Act (VAWA). Its title clearly delineates a woman focused initiative, and its chapeau and legislative history demonstrate overwhelming concern that the application of the new laws and policies benefit women, but the terms of the actual legislation are gender neutral. In general, the Roundtable favoured this approach to legislative initiatives.

\section{General Conclusions of the \\ Roundtable}

An optimum women's rights and human rights-protective approach would be directed at crimes against the trafficked and other vulnerable alien persons which would capitalize on the "currency" of trafficking while reaching a wider group of unprotected women and migrant workers.

In general, the consensus of the Roundtable participants was that people should be empowered to make autonomous decisions and that their decisions, freely made, should be respected and accepted. Voluntary activities that liberate people or result in actual improvements in the conditions of their lives-regardless of whether we "approve" of or desire such conditions for ourselves-should not be criminalized or actively prevented. Trafficking as a criminal offence and an interna- tional human rights violation should be defined so as to (1) maximize the protection of those who would find themselves transported to unfamiliar places and in abusive situations, and (2) minimize the ability of traffickers to lure them away in the first place and continue to abuse them after they have been trapped.

In the public meeting with government officials and others following the Roundtable, participants (as part of the working group in contact with each other as well as with the U.S. government) identified the root factors that make women particularly vulnerable to trafficking and trafficking abuses, including: the unequal status of women and girl-children in families and societies around the world; unequal access of women to employment, social benefits and educational opportunities; harmful stereotypes of women as property, commodities, servants and sexual objects; criminal justice systems that ignore and even perpetuate violence and discrimination against women; the world-wide feminization of poverty; export of labour and remittance policies in some countries that encourage women to work abroad and grant them few protections; promotion of sex tourism in some countries; and the demand for cheap, unprotected labour, including sexual services.

Participants also identified the following additional root factors that make poor people, and racial, ethnic, national and religious minorities and other disadvantaged people vulnerable to trafficking and trafficking abuses: protectionist and restrictive economic and migration policies which allow exploiters to prey on others' illegal or invisible or underground status; economic instability, poverty and the unequal distribution of wealth in sending countries and locales; the lucrative and relatively low-risknature of trafficking networks as opposed to other criminal enterprises and syndicates; and high levels of government and police complicity and corruption in sending, transit and receiving countries and locales; and the rise in anti-foreigner and antiimmigrant sentiment in many countries leading to increasing restrictions on le- 
gal entry and residency coupled with reduction of public services, including legal services, which prevent aliens from pursuing their fundamental rights and freedoms.

\section{Appendix 2}

Transnational Training Seminar on Trafficking in Women, An International Conference in Budapest, June 20-24, 1998

Co-Sponsors: Network Women's Program,Open Society Institute(BudapestNew York), Global Survival Network (Washington, D.C.)

The Transnational Training Seminar on Trafficking in Women was attended by representatives from more than 100 non-governmental organizations from 36 countries throughout Central and Eastern Europe (CEE), the Newly Independent States (NIS), Western Europe, Asia, the Middle East and North America, as well as the United Nations High Commissioner for Human Rights. Seminar participants affirmed that:

1) Trafficking consists of all acts involved in the recruitment or transportation of persons within or across borders, involving deception, coercion or force, abuse of authority, debt bondage or fraud, for the purpose of placing persons in situations of abuse or exploitation such as forced prostitution, slavery-like practices, battering and extreme cruelty, sweatshop labour or exploitative domestic servitude;

2) Trafficking may also involve kidnapping, false imprisonment, rape, battering, forced labour and slaverylike practices or other actions which violate fundamental human rights;

3) The worldwide trafficking of persons, which is condemned by the international community as a violation of fundamental human rights, has a disproportionate impact on women and girls;

4) The recentemergence of post-socialist countries in transition as countries of destination, transit and origin for trafficking in women demands an immediate response;

5) Thefundamental cause for the traffic in women is the economicinequality between and within countries, including the growing schism between urban and rural areas, and the socioeconomic inequality between women and men, especially in countries of origin. Governments must allocate sufficient resources to ensure the access of women to diverse forms of educationand employment. Seminar participants recommend that:

1) All government programs and international efforts related to trafficking should be developed in cooperation with non-governmental organizations. Further, governmental organizations and international donor institutions should provide financial support to non-governmental organizations working on the issue of trafficking;

2) Governmental measures and international efforts to address trafficking must focus on the human rights abuses and labour rights abuses of the women involved, rather than treating trafficking victims as criminals or as illegal migrants;

3) Governments must fulfill their obligations to combat trafficking and the abuses inherent in trafficking by enforcing and/or ratifying relevant treaties and conventions, including such treaties as the 1956 Supplementary Convention on the Abolition of Slavery, the Slave Trade and Institutions and Practices Similar to Slavery, which calls for the complete abolition of debt bondage and servile forms of marriage, and the 1957 Abolition of Forced Labour Convention, which undertakes to suppress and not to make use of any form of forced or compulsory labour, and the Convention on the Protection of the Rights of All Migrant Workers and their Families;

4) Government measures to address trafficking must focus on the promotion of the human rights of the women concerned and must not further marginalize, criminalize, stigmatize or isolate them, thus making them more vulnerable for violence and abuse;
5) States have a poditive obligation to protect the human rights of women, including sex workers;

6) Relevant governmentalbodies must collect and publish data on: a) government efforts to address instances of trafficking into, out of, and within their countries;

b) the successes or difficulties experienced in promoting interagency co-operation, co-operation between local and national authorities and cooperation with non-governmental organizations;

c) the treatment and service provided to trafficleing victims;

d) the disposition of trafficking cases in the criminal juatice syotem; and

e) the effects of govemmental legal and administrative measures onthe victims of trafficking, as defined in this resolution, and on thereduction of trafficking;

7) Trafficking victims muotbe gumanteed:

a) freedom frompercecution orharassment by those in positions of authority:

b) adequate, confidential and affordablemedied lend poycholested care by the State or, if no adequate State agency exiots, by a privativ agency funded by the Sute;

c) strictly confidential FIV testing service must be provided only if requested by the person concerned. Additionally, any and all HIV testing must be accompanied by appropriate pre and post-test counselling. TheStandard provided in the United Nations Centre for Human Rights and World Health Organisation Report of an International Consultation on AIDS and Human Rights, (Geneva, July 1989) must beadopted; d) access to a competent, qualified translator during all proceedings, and provision of all documents and records pursuant to having been a victim of trafficking and/or forced labour or slavery practices;

e) free legal assistance;

f) legal possibilities of compensation and redress for economic, and physical and psychological damage

Refuge, Vol. 17, No. 5 (November 1998) 
caused to them by trafficking and related offences;

8) The personal history, the alleged "character" or the current of previous occupation of the victim must not be used against the victim, nor serve as a reason to disqualify the victim's complaint or todecidenot to prosecute the offenders. The offenders must be prohibited from using as a defence the fact that the person is or was at any time, a sex worker or a domestic worker, for example;

9) The victim's history of being trafficked and/or being subjected to forced labour and slavery-like practices mustnotbea matter of public or private record and must not be used against the victim, her family or friends in any way whatsoever, particularly with regard to the right to freedom of travel, marriage, and search for gainful employment;

10) The State in the territory under whose jurisdiction the trafficking and/or forced labour and slaverylike practices took placemust take all necessary steps to ensure that the victim may press criminal charges and/or take civil action for compensation against the perpetrators, if they choose to do so;

11)Governments must:

a) implement stays of deportation and an opportunity to apply for permanent residency, witness protection, relocation assistance for trafficking victims;

b) implement asset forfeiture from criminal operations that profit from trafficking with funds set aside to provide compensation due to victims of trafficking;

12)In consultation with relevant nongovernmental organizations, relevant governmental bodies must:

a) develop curricula and conduct training for relevant government authorities, induding officials from immigration and consular affairs offices, customs services, border guard and migration services, and representatives of the Ministry of Foreign Affairs, regarding the prevalence and risks of being trafficked, and the rights of victims. The train- ing for such officials must not result in the creation of "profiles" which prevent women from receiving visas to go abroad;

b) develop awareness and education campaigns regarding trafficking to be conducted through mass media and community education programs;

c) distribute materials describing the potential risks of being trafficked, including:

i) information as to the rights of victims in foreign countries, including legal and civil rights in labour, marriage, and for crime victims; and

ii) the names of support and advocacy organizations in the origin, destination and transit countries.

\section{Appendix 3}

Established in 1994 at the International Workshop on Migration and Traffic in Women at the University of Chiang Mai, Thailand, GAATW International (Global Alliance Against Trafficking in Women) is an alliance of more than 200 women's organizations from around the world. GAATW Canada, which was formed two years later, is one of the few organizations in North America which specifically focuses on and addresses the issues of trafficked women, migrant women workers in the sex industry, domestic work, and the marriage market.

While strongly committed to combating the trafficking of women and the various abuses to which trafficked women are often subjected, the aim of GAATW Canada is not to stop the migration of women. Rather it is to safeguard and promote the human rights of a growing number of women who migrate and who are trafficked. Tenets held by GAATW emphasize the following rights of women: the right to paid work; to migrate; to safe, just and equitable working and living conditions; to just compensation; to organize, form unions, and bargain collectively; and to human dignity.

In order to protect and ensure the basic human rights of trafficked per- sons, GAATW, in conjunction with the Foundation Against Trafficking in Women, and the International Human Rights Law Group, has, as of January 1999, revised its existing Standards of Minimum Rules, outlined in the summary below. The prime objective of this revision process is to set international, regional and national standards for the treatment of victims of trafficking by:

1. developing a model guideline in the form of Standards for the Humanitarian Treatment of Trafficked Persons, which can be used as a lobbying instrumentby NGOs at the international, regional and national levels;

2. initiating and coordinating a campaign at the UN level for the setting of standards for the humanitarian treatment of victims of trafficking, seeking to ensure inclusion of the Standards in the UN Commission on Crime Prevention and Criminal Justice Protocol on Trafficking in Persons to the new Organised Crime Convention;

3. providing national level NGOswith a lobbying instrument to be used in advocating or standard setting at the national level.

\section{Standards For The Humanitarian Treatment of Trafficked Persons, January 1999}

These Standards aim to protect and promote respect for the human rights of individuals who have been victims of trafficking, including those who been subjected to forced labour and slaverylike practices. In particular, the Standards establish the right of trafficked persons to an effective remedy, protection, humanitarian treatment, and restitution, compensation and rehabilitation.

Under international law, States have a duty to respect and ensure respect for human rights and humanitarian law, including the duty to prevent violations, to investigate violations, to take appropriate action against the violators and to afford remedies and reparation to those who have been injured as a consequence of such violations. 
The following is an excerpt from the complete Standards, and further illustrates the ongoing efforts of organizations such as GAATW to best utilize existing laws and policies in their fight against trafficking:

\section{Definitions}

States shall review, evaluate and revise their laws, codes and procedures to ensure that they reflect the following definitions:

Trafficking: All acts and attempted acts involved in the recruitment, transportation within or across borders, purchase, sale, transfer, harbouring or receipt of a person involving the use of deception, coercion (including the use or threat of force or the abuse of authority) or debt bondage for the purpose of placing or maintaining such person in a situation of abuseor exploitation, whether for pay or not, such as forced labour in the garment, agricultural, fisheries, begging, sex or other labour sectors, forced domestic, sexual or reproductive services (including forced or servile marriages), forced extraction of body parts, or any other form of public or private forced labour, forced servitude or slavery-like practices.

Commentary: Trafficking can involve an individual or a chain of individuals starting with the recruiter and ending with the last person who buys or receives the victim (such as the owner of the sweatshop) or the person whoholds a person in conditions of slavery or subjects the person to slavery-like practices, forced labour or other servitude.

The core elements of the act of trafficking are the presence of deception, coercion or debt bondage and the exploitative or abusive purpose for which the deception, coercion or debtbondage is employed. Typically the deception involves the working conditions or the nature of the work to be done. For example, the victim may have agreed to work in the sex industry but not to be held in slavery-like conditions or to work in a factory but not in a brothel.

The nature of the labour or services provided, including those in the sex industry, are irrelevant to the question of whether or not the victim's human rights are violated. The focus of the definition is the trafficker's use of deceit, coercion, or debt bondage to force the victim to work in exploitative or abusive situations. These actions deprive the victim of her or his free will and ability to control her or his body, which constitutes serious violation of the fundamental rights of the trafficked person.

The definition reiterates existing international human rights standards prohibiting such acts. TheSlavery Convention, article 1(1), defines slavery as: "the status or condition of a person over whom any or all of the power attaching to the right of ownership are exercised." The Supplementary Convention to the Slavery Convention, article 1 , calls for the elimination of the slavery-like conditions in which many trafficked persons find themselves. It calls for "the complete abolition or abandonment ... [of] [d]ebt bondage, that is to say, the status or condition arising from a pledge by a debtor of his personal services or those of a person under his control as security for a debt, if the value of those services as reasonably.assessed is not applied towards the liquidation of the debtor the length and nature of those services arenot respectively limited and defined," forced marriages, the transfer of a woman "for value received or otherwise", and delivery of a child "to another person, whether for reward or not, with a view to the exploitation of the child or young person or of his labour." Article 6.2 prohibits the act of "induc[ing] another person to place himself or a person dependent upon him into the servile status resulting from any of the institutions or practices mentioned in article $1 . . . "$

The International Labour Organization also condemns such slavery-like practices. Article 2 of ILONo. 29 prohibits the use of forced or compulsory labour, defined as "all work or service which is exacted from any person under the menace of any penalty and for which the said person has not offered himself voluntarily." Also, article 4 holds that "[t]he competent authority shall not impose or permit the imposition of forced or compuleory labour for the benefit of private individuals, companies or associations."

Trafficked person: A person who is recruited, transported, purchased, sold, transferred, harboured or received as described in "Trafficking" above, including a child, as defined by and consistent with the principles in the Convention on the Rights of the Child, whether the child has consented or not.

Commentary: The definition distinguishes between adults who freely give theirfully-formed consent to migrate for work or other services (even if the conditions are known by the adult to be abusive or exploitative compared to the conditions under which other persons (particularly citizens) perform the same type of work) and adults who do not consent at all or whose apparent, implied or express consent is vitiated by the use of deception, coercion or debt bondage. It respects the right of adults to make decisions about their lives, including the decision that such work is preferable to other available options. However, the existence of consent does not excuse the abuser or exploiter from being subjected to the full force of other laws, such as laws of assault, unlawful detention, labour abuses and other criminal, administrative and civil offences. Lastly, the definition recognizes that children need special protection and that "consent" can never be a defence to a charge of trafficking in children.

Trafficker: A person who, or an entity that, intends to commit, is complicitous with, or acquiesces to, any of the acts described in "Trafficking" above.

Commentary: The definition is intended to punish only those persons or entities that have the requisite mental element, including persons and entities that intentionally remain ignorant of the manner in which their acts contribute to the trafficking chain. It excludes persons and entities that unwittingly (and without any reason to suspect the existence of trafficking) become a link in the trafficking chain, such as an innocent taxi driver or hotel owner. 


\section{Summary of the Standards}

Accordingly, the Standards adopt the [preceding] definition of trafficking and mandate the following State obligations towards trafficked persons:

Non-Discrimination: States shall not discriminate against trafficked persons in substantive or procedurallaw, policy or practice.

Protective Measures: States shall recognize that trafficked persons are victims of horrific crimes, protect their rights notwithstanding any irregular immigration status, and protect them from reprisal and harm.

Investigation and Prosecution: The police, prosecutors and court shall ensure that traffickers are punished and the rights of the victims to privacy, dignity and safety are safeguarded.

Civil Actions and Reparations: States must ensure that trafficked persons have a legal right to seek reparations from traffickers as well as assistance in bringing such actions, if necessary.

Resident Status: States shall provide trafficked persons with temporary residence visas (including the right to work) during the pendency of any criminal, civil or other legal actions and shall provide trafficked persons with the

rightto seek asylum and have the risk of retaliation considered in any deportation proceedings.

Health and Other Services: States shall provide trafficked persons with adequate health and other social services during the period of temporary residence.

Repatriation and Reintegration: States shall ensure that trafficked persons are able to return home safely. II

For the complete Standards for the $\mathrm{Hu}$ manitarian Treatment of Trafficked Persons, please contact the following:

\section{GAA TW Canada,}

141 Olive Street

Victoria, BC V8T 3M5 Phone/Fax:

(250) 480-1853 Email

gaatwcan@islandnet.com
Back Issues of Refuge, Canadas periodical on refugees

. Environmental Refugees, Vol. 12, No, 1, June 1992

2. Discussion of Immigration Bill C-86, Vol. 12, No. 2, July/(Aug.) 1992.

3. General Issue/Refugee Sponsorship, Vol. 12, No. 3, Sept. 1992.

4. Eastern European Refugees, Vol. 12, No. 4, Oct. 1992.

5. The Tragedy of Somalia, Vol. 12, No. 5, Nov./Dec. 1992.

6. The Review of Rejected Refugee Claims in Canada, Vol. 12, No. 6, Jan. 1993

7. Russia and Central Eurasia, Vol. 12, No. 7, February 1993.

8. Africa Issue: Repatriation, Vol. 12, No. 8, March 1993.

9. General Issue/Globalization, Vol. 13, No. 1, April 1993.

10. Russia and Central Eurasia, Vol. 13, No. 2, May 1993.

Special losue on Srilanka, Vol.13, No.3. June 1993.

12. Gender Issues and Refugee Law, Vol. 13, No. 4, July/Aug. 1993.

12. Gender lssues and Refugee Law, Vol. 13, No. 4, July/Au\&

13. Souheast Asian Refuges, Vol. 13, No. S, Sept. 1993.

15. Russia and Central Eurasia, Vol. 13, No. 7, Nov./Dec. 1993.

16. General Issue/Sudan, Vol. 13, No. 8, January 1994

17. Integration of Refugees-The Canadian Experience, Vol. 13, No. 9, Feb. 1994.

18. Refugees and Peace in Central America, Vol. 13, No. 10, March 1994.

19. Horn of Africa, Vol. 14, No. 1, April 1994

20. The Russian Federation, Vol. 14, No. 2, May 1994

21. The Former Yugoslavia, Vol. 14, No. 3, June/July 1994.

22. General Issue/IRB and Rebuilding Trust/Tamil Immigrants in Canada, Vol. 14, No. 4, Aug./Sept. 1994.

23. Rwandan Crisis, Vol, 14, No. 5 , October 1994

24. Refugee Resettlement in Israel, Vol. 14, No. 6, Nov. 1994

25. Refugee Women-Part 1: Issues, Vol. 14, No. 7, Dec. 1994

26. Refugee Women-Part 2: Case Studies, Vol. 14, No. 8, Jan. 1995

27. The Safe Third Country Concept, Vol. 14, No. 9, February 1995.

28. Special Issue on Chechnya, Vol. 14, No. 10, March 1995.

29. Reformulation of International Refugee Law, Vol. 15, No. 1, 1996 ,

30. Environment, Development and Refugees, Vol. 15, No. 2, 1996.

31. International Intervention in Refugee Crises, Vol. 15, No. 3, 1996

32. Early Warning on Humanitarian Crises, Vol. 15, No. 4, 1996

33. Child Refugees, Vol. 15, No. 5,1996

34. Global Settlement Services, Vol. 15, No. 6, 1997

35. Early Warning and Early Response, Vol. 16, No. 1, May 1997.

36. Uprooting and Consequences, Vol. 16, No. 2, June 199

37. Development-induced Displacement, Vol. 16, No. 3, August 1997

38. Refugee and Immigrant Women: An International Perspective, Vol. 16, No. 4 , October 1997.

39. Working with Refugees and Internally Displaced Persons, Vol. 16, No. 5 , November 1997.

40. Conflict, Population Displacement, and Conflict Resolution, Vol. 16, No. 6, December 1997.

41. Refugee and Immigrant Women: An International Perspective, Part II, Vol. 17, No. I, February 1998.

42. Human Rights and Refugee Movements in the Newly Independent States of the Former Soviet Union, Vol. 17, No. 2, April 1998.

43. Current Issues in Refugee and Human Rights Policy and Research, Vol. 17, No. 3 , August 1998.

44. Violent Displacement and Post-Conflict Reconstruction: Afghanistan, Uganda, and Rwanda, Vol. 17, No. 4, October 1998.

Single copy: Vol 12, $13 \& 14-\$ 6.50$; Vol 15, 16, 17-\$10. 10 percent discount on 3-9 issues (copies); 20 percent discount on 10 issues (copies) or more. Special discounts are available for students and exclusively volunteer-run NGOs. P. O. accepted.

Please send your orders to:

Centre for Refugee Studies, York University

Suite 333, York Lanes, 4700 Keele Street

Toronto, Ontario, Canada M3J 1 P3

Fax: (416) 736-5837・Email: refuge@yorku.ca・mswinder@yorku.ca 